\title{
EFFECT OF CHLORPROMAZINE ON THE CELL METABOLISM
}

\author{
IWAO YAMAMOTO, AKIRA TSUJIMOTO, YOSHIHARU TSUJIMURA, \\ MASATOSHI MINAMI AND YUTAKA KUROGOCHI \\ Department of Pharmacology, Nara Medical College, Nara \\ Received for publication February 28, 1957
}

Since H. Laborit (1) had been successful in "l'hibernation artificielle" with chlorpromazine and S. Courvoisier et al. (2) had reported the pharmacological properties of the drug, the possible therapeutic usefullness have been attempted for the treatment of neuropsychiatric disorders and the other diseases.

On the other hand, a few information could be found on the effect of chlorpromazine on the cell metabolism. A. Balesterieri (3) reported that the glucose oxidation was inhibited more eminently by the drug than phenobarbital, but the succinate oxidation was not affected. L. Perruzzo et al. (4) pointed out that the oxygen consumption of the brain slice in the chlorpromazine solution was reduced. F. Decourt et al. (5) showed that the fermentation of alcohol by yeast was not inhibited by the lower concentration of chlorpromazine and the phosphorylation in the fermentation was not affected.

Having been very much interested in the extensive clinical application of chlorpromazine without a satisfactory investigation of the effect on the cell metabolism, we have made an attempt at the study on the effect of this drug on the cell respiration.

\section{MATERIALS AND METHODS}

In this study "Contomin" (Yoshitomi) was employed as chlorpromazine hydrochloride, $\mathrm{N}$-(3'-dimethylaminopropyl)-3-chlorophenothiazine hydrochloride, that was indicative of $4560 \mathrm{RP}$.

\section{Measurement of the substrate oxidation}

The brain of intact albino rat weighing 150 to $200 \mathrm{~g}$ were chilled immediately after removal by immersion in 10 volume of Krebs-Ringer-phosphate buffer per gram of tissue and homogenized by Potter-Elvehjem glass homogenizer. The filtrate through muslin was used as $10 \%$ homogenate. The oxygen uptake was measured by the direct method of Warburg in the atomospheric condition at $37.5 \mathrm{C}$. The percentage of inhibition was calculated as follows; $(\mathrm{C}-\mathrm{Cs}) / \mathrm{C} \times 100$, where $\mathrm{C}$ and $\mathrm{Cs}$ were microliters of oxygen uptake without and with $4560 \mathrm{RP}$ respectively.

Assay for the cytochrome oxidase

The assay for the cytochrome oxidase was performed manometrically using endogenous cytochrome $\mathrm{c}, \boldsymbol{p}$-phenylenediamine as the reductant of cytochrome $c$, and 10 fold dilution of the homogenate as the enzyme preparation, 


\section{Estimation of the cysteine oxidation}

The cysteine oxidation was measured manometrically in borate buffer ( $1 \mathrm{~m}$ boric acid and $0.55 \mathrm{M} \mathrm{KOH}, \mathrm{pH} 7.0$ and 9.0 ) with $\mathrm{FeCl}_{3} \cdot 6 \mathrm{H}_{2} \mathrm{O}$ as ferric ion, and pyrophosphate buffer (0.2 $\mathrm{M}$ of purified $\mathrm{Na}_{4} \mathrm{P}_{2} \mathrm{O}_{\bar{i}}$ solution and $1 \mathrm{M} \mathrm{HCl}, \mathrm{pH} 7.0$ ), for the inactivation of ferric and manganic ions, with $\mathrm{CuSO}_{4} \cdot 5 \mathrm{H}_{2} \mathrm{O}$ as cupric ion, at $25 \mathrm{C}$ with air in the gas phase.

\section{Determination of the D-alanine oxidase}

The rat kidney homogenate, which was prepared by the same technique as the brain, was used as the preparation of $D$-alanine oxidase. The activity of the $D$-alanine oxidase was measured by the rate of oxygen consumption.

Testing method of the dehydrogenase system

The brain homogenate was suitably diluted with Krebs-Ringer-phosphate buffer to give 20 minutes of the decoloring time of the acceptor. The concentrations of acceptors were $2 \times 10^{-5} \mathrm{M}$ and $4 \times 10^{-5} \mathrm{M}$ of methylene blue $(\mathrm{Mb})$ and toluylene blue (Tb) and $1.33 \times$ $10^{-5} \mathrm{M}$ of nile blue $(\mathrm{Nb})$. The Thunberg technique was employed for the assay of dehydrogenase activity. The decoloring time of acceptors were measured. The inhibition was indicated as follows: $(\mathrm{V}-\mathrm{Vs}) / \mathrm{V} \times 100$, where $\mathrm{V}$ and $\mathrm{Vs}$ were reciprocals of decoloring time without and with $4560 \mathrm{RP}$ respectively.

\section{Measurement of the oxidative phosphorylation}

The rat brain homogenate, which was prepared with 7 volume of Krebs-Ringer-phosphate buffer per gram of tissue, $\mathrm{pH} 7.2$, was used as the enzyme preparation. The reaction system, the modification of S. Ochoa's method (6), contained as follows; brain homogenate, $1 \mathrm{ml}$; $0.01 \mathrm{M} \mathrm{K}$-ATP, $0.3 \mathrm{ml} ; 0.2 \mathrm{M} \mathrm{MgSO}$, $0.2 \mathrm{ml} ; 0.25 \mathrm{M} \mathrm{NaF}, 0.2 \mathrm{ml} ; 0.3 \mathrm{M}$ glucose, $0.2 \mathrm{ml}$; $0.15 \mathrm{M}$ substrate, $0.2 \mathrm{ml},(0.05 \mathrm{M}$ fumarate, $0.2 \mathrm{ml}$ as sparker $)$. Oxygen consumption was measured manometrically at $37.5^{\circ} \mathrm{C}$ with air in the gas phase and high-energy phosphate bond synthesis was determined by the disappearance of inorganic phosphate from the reaction medium. The estimation of inorganic phosphate was made by the method of C.H. Fiske et al. (7) using the filtrate with trichloracetic acid. P:O ratio was obtained by the ratio of the mole of inorganic phosphate esterified per atom of oxygen consumed after 15 minutes' incubation.

\section{RESULTS}

The effect of $4560 R P$ on the endogenous respiration

The endogenous respiration was inhibited by $78 \%$ at the concentration of $10^{-3} \mathrm{M}$ of 4560RP, but scarcely inhibited at $10^{-4} \mathrm{M}$ as shown in Fig. 1 .

The effect of $4560 R P$ on the oxidation of several substrates

The most distinct inhibition of 4560RP was observed when glucose was used as substrate. The 4560RP inhibition with lactate, glutamate, pyruvate, citrate, malate and fumarate as substrates were nearly equal. The succinate oxidation was also inhibited by $14 \%$ at the concentration of $3.3 \times 10^{-4} \mathrm{M}$ (Table 1). 4560RP did not inhibit, however, with any substrate at its concentration of $10^{-4} \mathrm{M}$, 


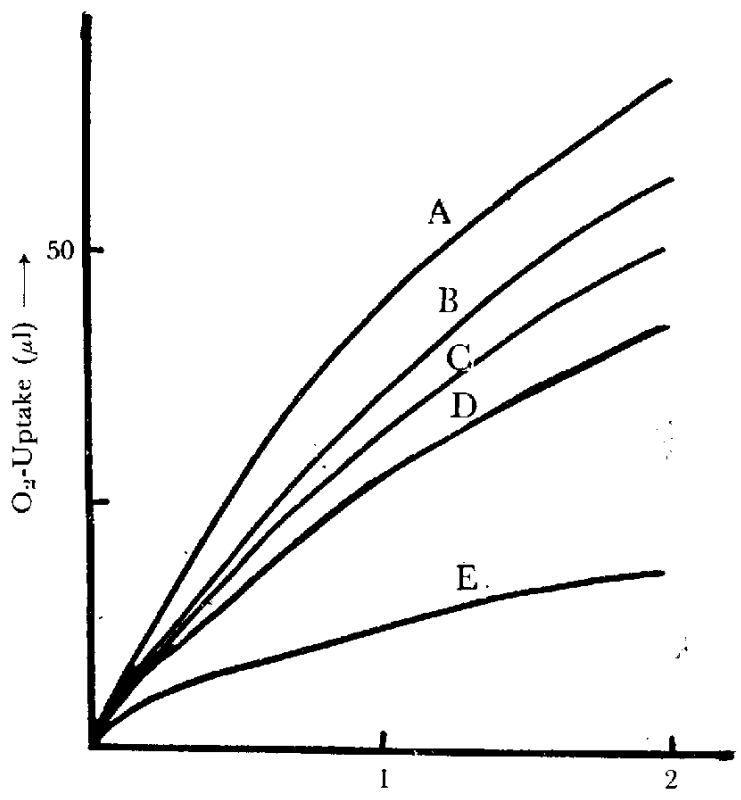

Time (hrs) $\longrightarrow$

TAHIE 1. The degree of 4560RP inhibition of the bran respiration in the presence of substrates.

Each flask contained the following: $0.5 \mathrm{mI}$ of 109 , brain homogenate; $0.5 \mathrm{ml}$ of Krebs-Ringer-phosphate solution; $0.5 \mathrm{ml}$ of substrate* ; drug concentrations as shown, in the side arm; $0.3 \mathrm{ml}$ of $20 \% \% \mathrm{KOH}$, in the center well. Conditions were the same as listed under Fig. 1.

\begin{tabular}{|c|c|c|c|c|c|}
\hline $\begin{array}{r}\text { Inhibition } \\
(0 \%)\end{array}$ & & & $60 \mathrm{RP}$ & & \\
\hline Substrate & $1 \times 10^{-3}$ & $5 \times 10$ & $3.3 x$ & $2 \times 10^{-}$ & $\times 10^{-4}$ \\
\hline Glucose & & 73 & 48 & 37 & 15 \\
\hline Lactate & & 66 & 45 & 29 & 10 \\
\hline Pyruvate & 73 & 65 & 34 & 24 & 8 \\
\hline Glutamate & & $6 I$ & 40 & 26 & 9 \\
\hline Citrate & & 46 & 37 & 26 & 9 \\
\hline Succinate ${ }^{* *}$ & 49 & 17 & 14 & & \\
\hline Fumarate & & 58 & 37 & 27 & 10 \\
\hline Malate & & 58 & 36 & 14 & 8 \\
\hline
\end{tabular}

* : $0.033 \mathrm{M}$ glucose, sodium glutamate, sodium citrate, sodium fumarate and sodium malate, $0.2 \mathrm{M}$ sodium lactate and sodium pyruvate, $0.1 \mathrm{M}$ sodium succinate were employed

**: $0.3 \mathrm{ml}$ of $100^{\circ}$; brain homogenate

Fach flask contained the following: $1 \mathrm{ml}$ of 10\% brain homogenate; $0.5 \mathrm{ml}$ of Krebs-Ringer-phosphate solution; drug concentrations as shown, in the side arm $(0.5 \mathrm{ml}$ of distilled water was added to control flask) $0.3 \mathrm{ml}$ of $20 \% \mathrm{KOH}$, in the center well. 'T'he gas phase was air and the temperature $37.5^{5} \mathrm{C}$.

Curve A : Endogenous

Curve B : $3.3 \times 10^{-4}$ M $4560 \mathrm{RP}$

Curve $\mathrm{C}: 4.0 \times 10^{-4} \mathrm{M} 4560 \mathrm{RP}$

Curve D : $5.0 \times 10^{-4} \mathrm{M} 4560 \mathrm{RP}$

Curve E : $10 \times 10^{-4} \mathrm{M} 4560 \mathrm{RP}$

It is well known that 2,4-dinitrophenol (DNP) accelerates the cell respiration at lower concentration. Fig. 2 shows that $4560 \mathrm{RP}$ diminishes the acceleration of respiration with DNP $\left(5 \times 10^{-5} \mathrm{M}\right)$ when glucose is used as substrate.

The effect of $4560 R P$ on the p-phenylenediamine oxidation

As the oxidation of $p$-phenylenediamine was inhibited by $4560 \mathrm{RP}$, the inhibition was compared with $\mathrm{KGN}$, which was a typical inhibitor of the cytochrome oxidase, giving the results shown in Fig. 3.

The effect of $4560 R P$ on the cysteine oxidation

Fig. 4 shows the effect of $4560 \mathrm{RP}$ on the cysteine oxidation with $0.1 \mathrm{ml}$ of $3.3 \times 10^{-4}$ $\mathrm{M} \mathrm{FeCl}_{\mathbf{3}}(18.6 \mu \mathrm{g})$ as catalyst.

The inhibition with $3.3 \times 10^{-3} \mathrm{M} 4560 \mathrm{RP}$ was increased proportionally to the concentration of ferric ion which was decreased as shown in Fig. 5.

It was observed in each case that the inhibition on the cysteine oxidation at 30 minutes was more distinct than at 60 minutes. The similar observations were tried in alkaline medium 


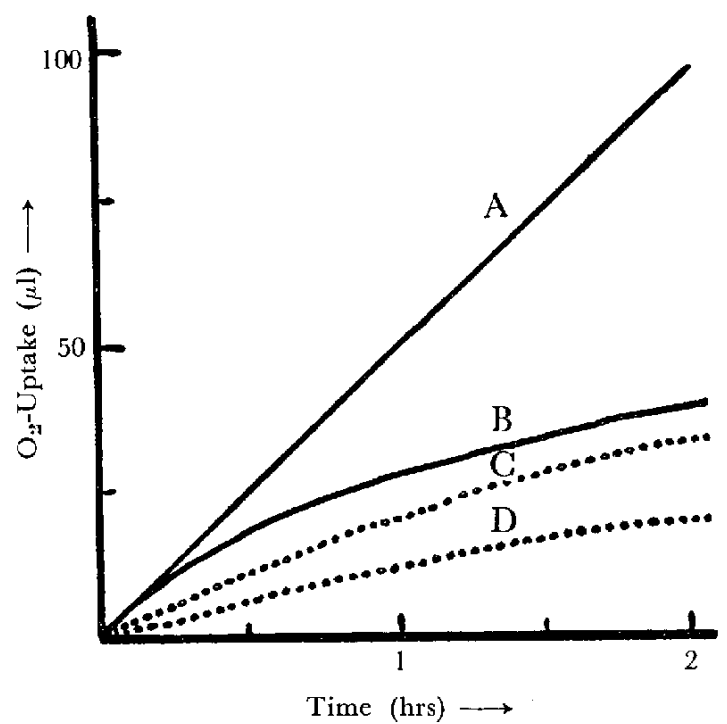

Fig. 2. Effect of $4560 \mathrm{RP}$ on the augmentation of DNP with glucose as substrate.

The experimental flasks contained $2 \times 10^{-4} \mathrm{M}$ and $5 \times 10^{-5} \mathrm{M}$ DNP. All other components and conditions were the same listed on Table 1.

Gurve A : DNP:glucose

Curve B : DNP : $4560 \mathrm{HP}+$ glucose

Gurve $\mathrm{C}$ : Glucose

Curve D : 4560RP

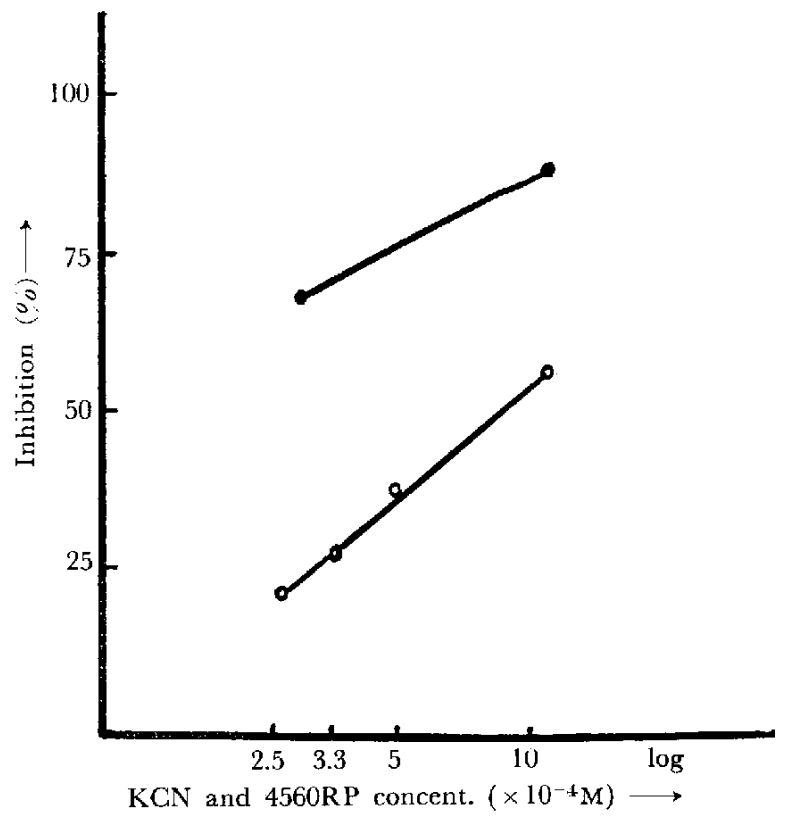

FIG. 3. The inhibition of $4560 \mathrm{RP}$ and $\mathrm{KCN}$ on $p$-phenylenediamine oxidation.

Each flask contained the following : $0.3 \mathrm{ml}$ of $10 \%$ brain homogenate; $0.5 \mathrm{ml}$ of $0.1 \mathrm{M} p$-phenylenediamine; drug concentrations as shown, in the side arm,

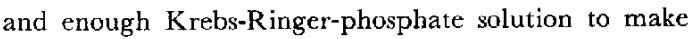
$2 \mathrm{ml}$. Conditions were the same as listed under Fig. 1.

$0-0$ : Degree of 4560RP inhibition

- Degree of KCN inhibition

of the purpose of comparing with $\mathrm{KCN}$, which inhibited at $\mathrm{pH} 9.4$, but not at $\mathrm{pH} 7.0$ as shown in Table 2. It could not be tested, however, owing to insolubility of 4560RP in alkaline medium.

When $3.3 \times 10^{-5} \mathrm{M}$ of $\mathrm{CuSO}_{4}$ was used as a catalyst, $2 \times 10^{-3} \mathrm{M} 4560 \mathrm{RP}$ was wanting in the inhibition of the cysteine oxidation, though KCN showed nearly complete inhibition over 60 minutes at the same molar concentration. Furthermore no inhibition of 4560RP was observed when the concentration of cupric ion was reduced to half or a quarter.

The effect of $4560 R P$ on the D-alanine oxidation

$4560 \mathrm{RP}$ did not affect the oxidation of $D$-alanine at its concentration of $3.3 \times 10^{-3} \mathrm{M}$, wherc it revealed the certain inhibition with the other substrates mentioned above.

The effect of $4560 R P$ on the dehydrogenase system

The dehydrogenase activities with glucose, lactate, pyruvate, glutamate, malate and succinate as donators wcre inhibited by $4560 \mathrm{RP}$ with $\mathrm{Mb}$ as acceptor. Glucose was the most scnsitive as similar as in the case of the oxygen consumption. 4560RP inhibited the succinate dehydrogenase by $50 \%$ at its concentration of $3.3 \times 10^{-3} \mathrm{M}$. The $4560 \mathrm{RP}$ inhibition. 


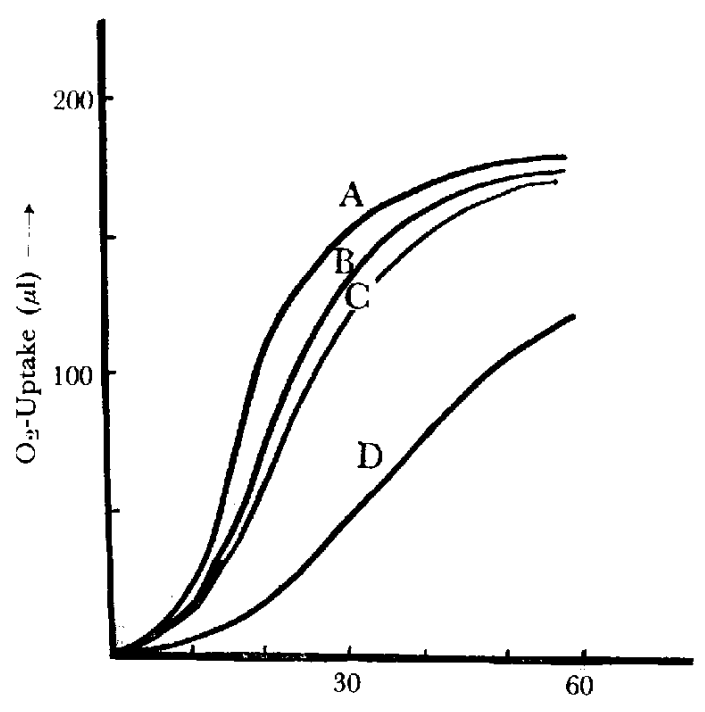

Time (min) $\longrightarrow$

FIG. 4. The effect of 4560 RP on the oxidation of cysteine with ferric ion as catalyst.

Each flask contained the following: $1.9 \mathrm{ml}$ of borate buffer, $\mathrm{pH} 7.0 ; 0.4 \mathrm{ml}$ of $15 \mathrm{mg} / \mathrm{ml}$ cysteine; $0.1 \mathrm{ml}$ of $3.3 \times 10^{-3} \mathrm{M} \mathrm{FeCl}, 6 \mathrm{H}_{2} \mathrm{O}$; drug concentrations as shown, in the side arm $(0.6 \mathrm{ml}$ of distilled water was added to control flask). The gas phase was air and the temperature $25^{\circ} \mathrm{C}$.

Gurve A : Control

Curve B : Effect of $5 \times 10^{-4}$ M 4560RP

Curve C : Effect of $1 \times 10^{-3}$ M 4560RP

Curve D: Effect of $2 \times 10^{-3}$ M 4560RP

TABLE 2. The effect of KCN on the oxidation of cysteine with ferric ion as catalyst.

Each flast contained $1.9 \mathrm{ml}$ of borate buffer, $\mathrm{pH} 7.0$ or $\mathrm{pH}$ 9.4. All other components and conditions were the same as listed under Fig. 4.

\begin{tabular}{|c|c|c|c|}
\hline & \multirow{2}{*}{ Control } & \multicolumn{2}{|c|}{$\mathrm{KCN}$} \\
\hline & & $2 \times 10^{-3} \mathrm{M}$ & $1 \times 10^{-3} \mathrm{M}$ \\
\hline $\begin{array}{c}\text { Os-Uptake }(\mu \mathrm{l} / \mathrm{hr}) \\
(\mathrm{pH} \mathrm{9.4)}\end{array}$ & 100 & 9 & 20 \\
\hline Inhibition & & 910 & $80 \%$ \\
\hline $\begin{array}{c}O_{-} \text {-Uptake }(\mu \mathrm{l} / \mathrm{hr}) \\
(\mathrm{pH} 7.0)\end{array}$ & 141 & 150 & 160 \\
\hline
\end{tabular}

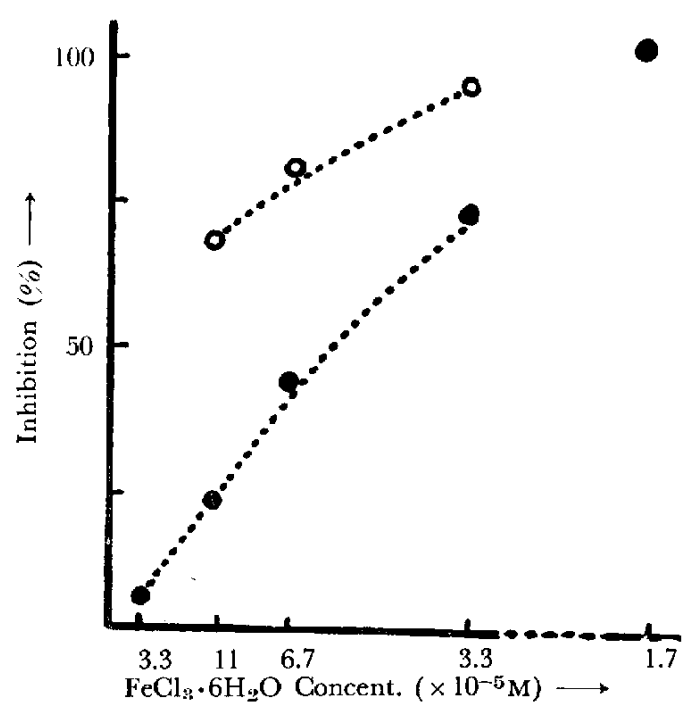

FIG. 5. The effect of ferric ion concentration on the 4560RP inhibition of the cysteine oxidation.

The experimental flasks contained $3.3 \times 10^{-3} \mathrm{M}$ 4560 RP. All other components and conditions were the same as listed under Fig. 4.

o.... : Inhibition at $30 \mathrm{~min}$

-...... Inhibition at $1 \mathrm{hr}$

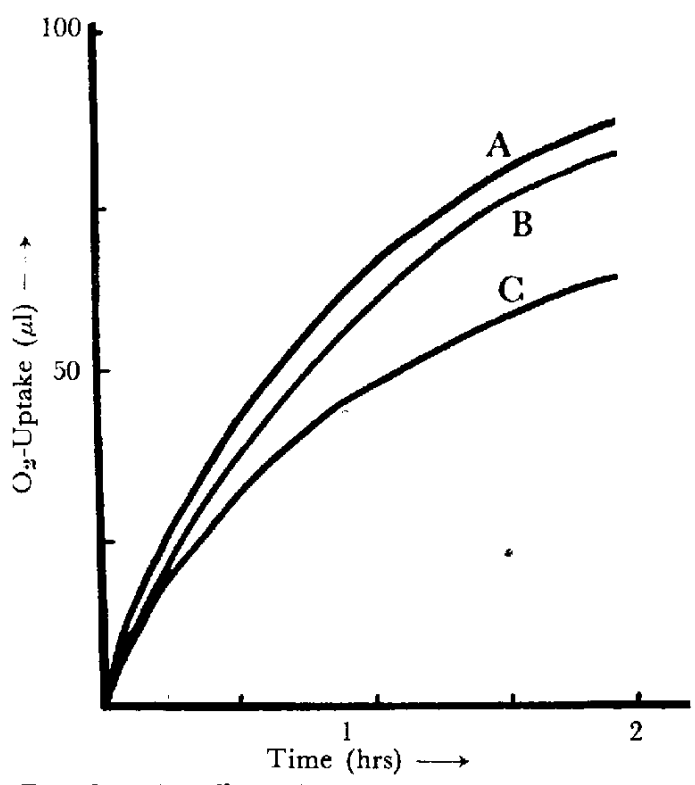

FIG. 6. The effect of 4560RP on the oxidation of $D$-alanine in kidney.

Each flask contained the following: $0.5 \mathrm{ml}$ of K rebs-Ringer-phosphate solution; $0.5 \mathrm{~mL}$ of $10^{\circ} \circ$ kidney homogenate; $0.5 \mathrm{ml}$ of $0.1 \mathrm{M} D$-alanine; drug concentrations as shown, in the side arm. Conditions were the same as listed under Fig. 1.

Curve A: Control

Curve B : Effect of $3.3 \times 10^{-4}$ M 4560RP

Gurve $\mathrm{C}$ : Effect of $5 \times 10^{-1} \mathrm{M} 4560 \mathrm{RP}$ 
was slightly less than that with $\mathrm{Mb}$ when $\mathrm{Tb}$ was used as an acceptor, but it was not observed with $\mathrm{Nb}$ (Table 3).

TABLE 3. The effect pf 4560RP on the nile blue, methylene blue and toluylene blue decoloring time with glucose, lactate, pyruvate. glutamate, succinate and malate as donators.

Each tube contained the following : $0.8 \mathrm{ml}$ of Krebs-Ringer-phosphate solution; $1 \mathrm{ml}$ of $2 \%$ brain homogenate; $0.1 \mathrm{ml}$ of $3.3 \times 10^{-4} \mathrm{M}$ nile blue; $0.1 \mathrm{ml}$ of $10^{-3} \mathrm{M}$ methylene blue; $0.1 \mathrm{ml}$ of $10^{-3} \mathrm{M}$ toluylene blue; drug concentrations as shown $(0.5 \mathrm{ml}$ of distilled water was added to control tube). The temperature was $37.5^{\circ} \mathrm{C}$.

\begin{tabular}{|c|c|c|c|c|c|c|}
\hline \multirow{4}{*}{ Donator } & \multicolumn{6}{|c|}{ Inhibition $(0)$} \\
\hline & Nile blue & \multicolumn{3}{|c|}{ Methlene blue } & Toluylene & e blue \\
\hline & \multicolumn{6}{|c|}{ 4560RP (M) } \\
\hline & $3.3 \times 10^{-4}$ & $3.3 \times 10^{-4}$ & $2 \times 10^{-4}$ & $1 \times 10^{-4}$ & $3.3 \times 10^{-1}$ & $2 \times 10^{-4}$ \\
\hline Glucose & 7 & 80 & 60 & 12 & 74 & 44 \\
\hline Lactate & 3 & 58 & 25 & 3 & 45 & 35 \\
\hline Pyruvate & 0 & 59 & 35 & 8 & 60 & 41 \\
\hline Glutamate & 11 & 59 & 27 & 16 & 57 & 45 \\
\hline Succinate & 10 & 57 & 20 & 3 & 18 & 0 \\
\hline Malate & & 50 & 25 & 12 & & \\
\hline
\end{tabular}

The effect of $4560 R P$ on the oxidative phosphorylation

4560RP inhibited the oxidative phosphorylation with pyruvate, glutamate, citrate and succinate as substrates. The inhibitions were near completion at $10^{-3} \mathrm{M}$ of $4560 \mathrm{RP}$ with each substrate. P:O ratio, however, was scarcely altered at less concentration than $3.3 \times$ $10^{-4} \mathrm{M}$ of $4560 \mathrm{RP}$ (Fig. 7-9).

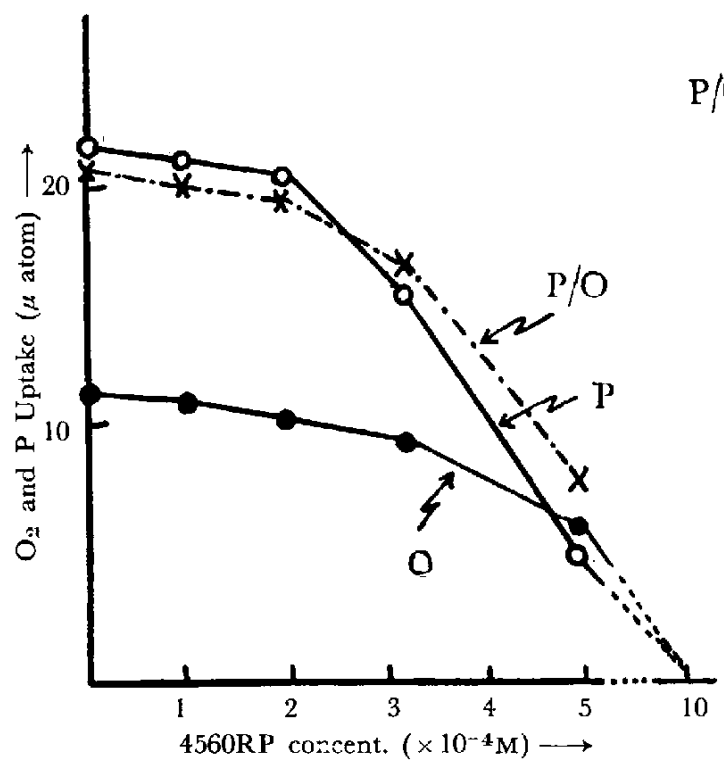

FIG. 7. The effect of 4560 RP on the oxidative phosphorylation with pyruvate as substrate.

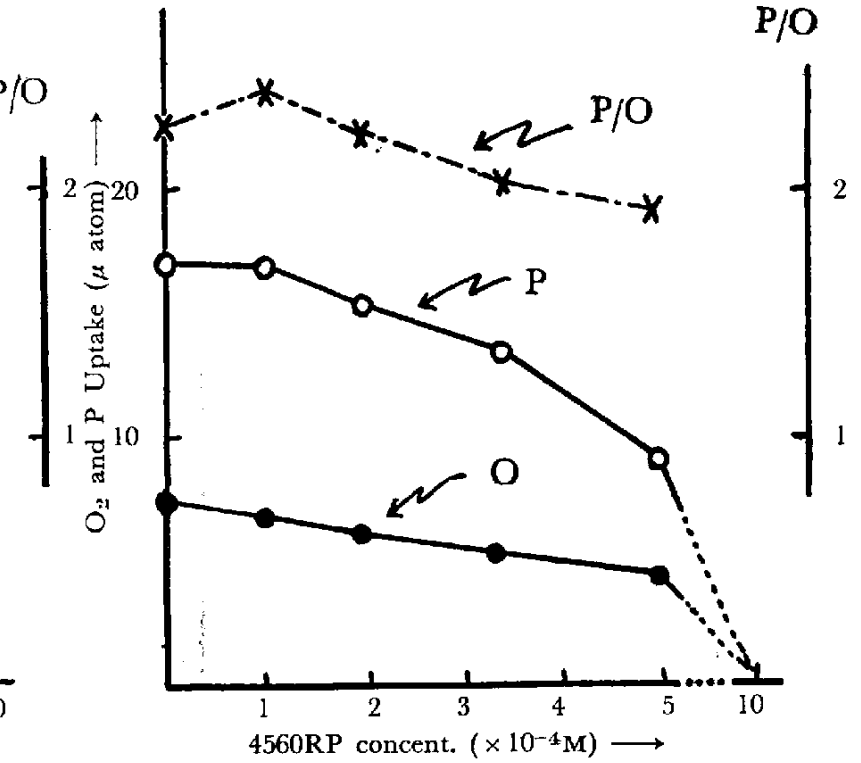

FIG. 8. The effect of 4560RP on the oxidative phosphorylation witn glutamate as substrate. 


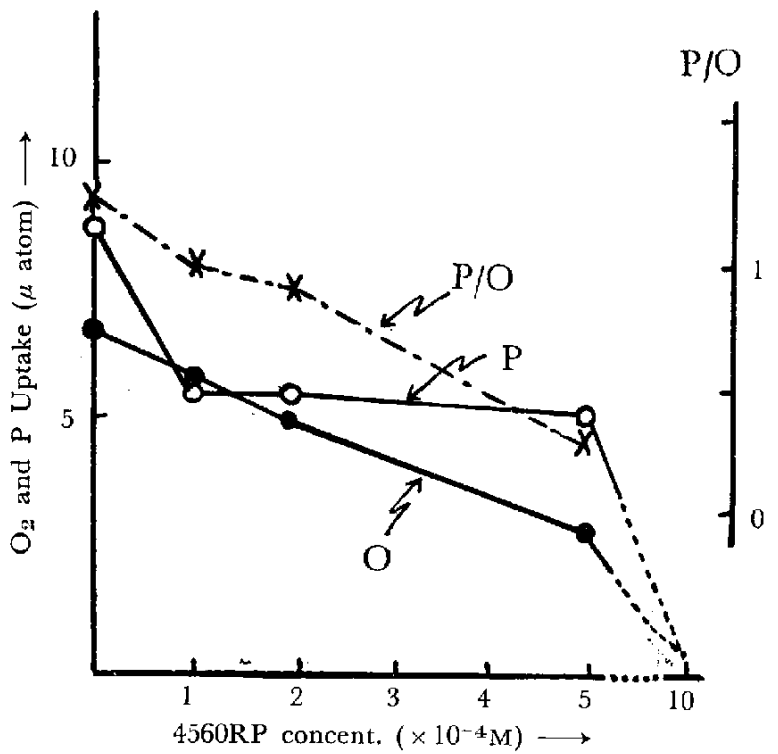

FIG. 9. The effect of $4560 \mathrm{RP}$ on the oxidative phosphorylation with succinate as substrate.
DISCUSSION

It has been announced that 4560 RP decreased the basal metabolism followed by manifestation of various pharmacological actions $(8,9)$. Now, it was revealed that $4560 \mathrm{RP}$ inhibited the endogenous respiration and the oxidations of various substrates at its concentration of $10^{-3}$ to $2 \times 10^{-4} \mathrm{M}$. The result obtained with glucose as a substrate was agreed upon that of A. Balesterier (3). The succinate oxidation, however, was also inhibited by $14 \%$ at $3.3 \times 10^{-4} \mathrm{M}$ of $4560 \mathrm{RP}$. This result disagreed with his report. Hence, these results might suggest the causation of the decrease of the

basal metabolism reported H. Laborit (10) and A. Loeser et al. (6).

On the other hand, it would be worthy of notice that the $p$-phenylenediamine oxidation was inhibited by $4560 \mathrm{RP}$. This fact called our attention to the relationship between $4560 \mathrm{RP}$ and ferric ion, which was a principal factor of the hydrogen transmission as to the cytochrome oxidase or cytochrome c (11). The relationship between 4560R $\mathrm{P}$ and ferric ion was observed by mean of the cysteine oxidation. When $0.1 \mathrm{ml}$ of $3.3 \times 10^{-4} \mathrm{M} \mathrm{FeCl}_{3}(\mathrm{Fe}$ content was $18.6 \mu \mathrm{g}$ ) was used as a catalyst, the great part of cysteine was oxidized within 30 minutes and the oxidation became nearly the rate-limit at 60 minutes. This cysteine oxidation was inhibited by 4560RP. The degree of the inhibition at 30 minutes was 3 times as much as at 60 minutes. The results suggested that 4560RP delayed the rate of the reaction. A decrease in the ferric ion concentration resulted in an increase in the 4560RP inhibition on the cysteine oxidation. When cupric ion was used as a catalyst the 4560RP inhibition of the cysteine oxidation was not observed, on the contrary KCN inhibited the oxidation. These results indicate that the inhibition mechanism of 4560RP on the cytochrome oxidase in different from that of $\mathrm{KCN}$, which forms the complex with metals such as iron and copper. As it was demonstrable that the other phenothiazine derivatives, including promethazine and diethazine, inhibited the $p$-phenylenediamine oxidation and the cysteine oxidation with ferric ion as a catalyst, but not with cupric ion, further studies have been made in this laboratory (12).

Furthermore, the $D$-alanine oxidase, which was not involved in the cytochrome oxidase system, was not affected by $3.3 \times 10^{-4} \mathrm{M} 4560 \mathrm{RP}$, but was slightly inhibited by $5 \times 10^{-4} \mathrm{M}$. So, it could not be negligible for 4560RP to inhibit not only the cytochrome oxidase but also 
the other respiration enzyme system.

Then the effect of 4560RP on the dehydrogenase system was observed. When $\mathrm{Mb}$ was used as an acceptor the 4560RP inhibitions on the dehydrogenases were corresponding to that on the oxygen consumptions with the same kinds of substrates. It was demonstrated under the anaerobic condition, too, that 4560RP inhibited the succinate dehydrogenase. When $\mathrm{Nb}$ was employed as an acceptor, which possessed a lower oxidation-reduction potential $\left(\mathrm{Eo}^{\prime}=-0.142\right.$ at $\left.\mathrm{pH} 7.0\right)$ than that of $\mathrm{Mb}\left(\mathrm{Eo}^{\prime}=+0.011\right.$ at $\left.\mathrm{pH} 7.0\right)$, the $4560 \mathrm{RP}$ inhibitions were not observed. The inhibitions, however, with $\mathrm{Tb}$ as an acceptor, which possessed a higher oxidation-reduction potential $\left(\mathrm{Eo}^{\prime}==+0.115\right.$ at $\left.\mathrm{pH} 7.0\right)$, were confirmed, though the degree of the inhibition was slightly less than that with Mb. 4560RP might inhibit the hydrogen transmission possessed an oxidation-reduction potential which was adjacent to that of $\mathrm{Mb}$.

In the meanwhile, it was demonstrated that when glucose was used as a substrate 4560RP made void the accerelative effect on respiration of the lower concentration of DNP, which was a well-known uncoupler of the oxidative phosphorylation. And 4560RP was so sensitive to the glucose oxidation, that the effect of $4560 \mathrm{RP}$ on the oxidative phosphorylation conjugated with the substrate oxidation was investigated. Almost complete inhibition was observed at its concentration of $10^{-3} \mathrm{M}$, though $\mathrm{P}: \mathrm{O}$ ratio was scarcely altered at less than $3.3 \times 10^{-4} \mathrm{M}$.

Recently, L. Abood (13) and J. Bernsohn et al. (14) also confirmed that 4560RP inhibited the oxidative phosphorylation and the cytochrome oxidase of the rat brain mitochondria.

\section{SUMMARY}

1. $4560 \mathrm{RP}$ inhibits the endogenous respiration and aerobic oxidation of various substrates by the rat brain homogenate at its concentration of $10^{-3} \mathrm{M}$ to $2 \times 10^{-4} \mathrm{M}$.

2. 4560RP inhibits the oxidations of $p$-phenylencdiamine by the brain homogenate and of $D$-alanine by the kidney homogenate. The cysteine oxidation with ferric ion is inhibited by $4560 \mathrm{RP}$. A decrease in the ferric ion concentration results in as increase in the $4560 \mathrm{RP}$ inhibition.

3. 4560RP inhibits the dehydrogenase system with methylene blue and toluylene blue as acceptors but not with nile blue. The results suggest that 4560RP inhibits the hydrogen transmission to possess an oxidation-reduction potential which is adjacent to that of methylene blue.

4. 4560RP inhibits the oxidative phosphorylation. Alteration of $\mathrm{P}: \mathrm{O}$ ratio is not obvious at less concentration than $3.3 \times 10^{-4} \mathrm{M}$.

This work was presented before the proceedings of the Japanese Pharmacological Socicty, Nov. 20, 1955 and April 5, 1956. 


\section{REFERENCES}

1) LABorit, H., JAUMES, C. AND BENiTTE, A.: Anésth. et analg. 9, 232 (1952)

2) Courvoisier, S. AND FourNel, J.: Arch. int. Pharmacodyn. 92, 305 (1952)

3) BALESTRIeRI, A. AND BERIT, T.: Bull. soc. ital. biol. sper. 29, 1669 (1952)

4) Perruzzo, L. AND Torni, R.B.: Presse méd. 61, 72 (1953)

5) DeCour'T, P.: C. R. Soc. Biol. 147, 1767 (1953)

6) OсноA, S.: J. biol. Chem. 151, 493 (1943); 155, 87 (1944)

7) FISKE, C.H. AND SUBBAROW, Y.: Ibid. 66, 375 (1925): 81, 629 (1929)

8) HUGUeNARD, P.: Ibid. 3, 32 (1954)

9) Filk, H., RitTer, K., STRUemer, E. AND Loeser, A.: Klin. Wschr. 32, 265 (1954)

10) LABORIT, H.: Anaesthesis 1, 20 (1954)

11) WARBURG, O. AND NEgelein, E.: Biochem. Z. 113, 257 (1921)

12) YaMAMOTO, I. et al.: unpublished

13) ABOOD, L.G.: Proc. Soc. exp. Biol. \& Med. 88, 688 (1955)

14) Bernsohn, J., Namajuska, I. ANd Cochrane, S.G.: Ibid. 92, 201 (1956) 